\title{
PENENTUAN KOMPOSISI OPTIMUM BUBURAN KERTAS KRAFT LINER 150 GSM MENGGUNAKAN METODE MIXTURE EXPERIMENT (Studi kasus: Pabrik Pulp \& Paper PT.Z)
}

\author{
Johnson Saragih ${ }^{*}$, Aldy Maulana \\ Jurusan Teknik Industri Universitas Trisakti Jakarta
}

\begin{abstract}
Abstrak
Tujuan dari penelitian ini adalah bagaimana caranya memilih komposisi dari campuran buburan kertas sehingga posisi optimum dapat tercapai, dengan tercapainya komposisi optimum tersebut diharapkan dapat meningkatkan kualitas kertas yang diproduksi.Adapun komposisi buburan kertas yang ingin dicapai adalah konsistensi sebesar untuk campuran $4.0 \pm 0.5$, pada campuran satu, tingkat freeness sebesar $350 \pm 50 \mathrm{ml}$ pada campuran dua dan tingkat internal bonding sebesar $300 \pm 10 \mathrm{~J} / \mathrm{m}^{2}$ pada campuran tiga.

Percobaan dilakukan dengan metoda mixture experiment untuk sampel percobaan buburan kertas sebanyak 500 gr. Titik percobaan dibangkitkan dengan software minitab sebanyak 14 titik percobaan.Adapun komposisi campuran yang optimal diperoleh untuk total campuran diperoleh sebesar $71.23 \%$ ( 356.15 gr) Waste Paper, 8.72\% (43.55gr) Pulp (NUKP), 3.54\% (17.7 gr) Air, 5.7\%(28.5 gr) Rosin, $3.29 \%$ (16.4 gr) Aluminium Sulfat $\left(\mathrm{Al}_{2}\left(\mathrm{SO}_{4}\right)_{3}\right)$, dan $7.55 \%$ (37.75gr) Starch. Dengan komposisi tersebut akan dihasilkan produk yang memenuhi spesifikasi yang telah ditetapkan perusahaan.

Berdasarkan pengukuran kapabilitas proses campuran satu, pada kertas kraft liner $150 \mathrm{gsm}$ di perusahaan untuk tingkat konsistensi, adalah sebesar 0.47 dan setelah dilakukan percobaan yang optimal, berubah menjadi 1.11 berarti terdapat peningkatan sebesar $136.7 \%$.Pada campuran dua untuk tingkat freeness adalah 0.45 berubah menjadi 1.14 berarti meningkat sebesar $153.3 \%$, sedangkan pada campuran tiga untuk tingkat internal bonding dari 0.55 berubah menjadi 1.15 berarti meningkat sebesar $109 \%$.
\end{abstract}

Kata kunci: mixture experiment; konsistensi; freeness; internal bonding

\begin{abstract}
The aim of the research are how to choose composition from pulp paper mix, so that optimum position can be achieved, with the achievement of optimum composition, it can be expected to increase quality of paper production. While the pulp paper composition to achieve are consistency as big as

$4.0 \pm 0.5$ for mixing on first mix, freeness level as big as $350 \pm 50 \mathrm{ml}$ on second mix and internal bonding as big as $300 \pm 10 \mathrm{~J} / \mathrm{m}^{2}$ on third mix.

Trial is done with mixture experiment method for pulp paper, trial sample as big as 500 gr.trial point raised with minitab software as big as 14 trial point. While optimal mix composition obtain as big as 71.23\% (16.4 gr) Waste Paper, 8.72\%(43.55gr) Pulp(NUKP), 3.54\%(17.7gr)Water ,5.7\%(28.5 gr) Rosin, $3.29 \%(16.4 \mathrm{gr})$ Aluminium Sulfat $\left(\mathrm{Al}_{2}\left(\mathrm{SO}_{4}\right)_{3}\right)$ and $7.55 \%(37.75 \mathrm{gr})$ Starch. With the composition will produced a product that meet the specification the company set.

Based on process capability first mix, on kraft liner $150 \mathrm{gsm}$ paper in the company for consistency level are 0.47 and after optimal trial been done turn to 1.11, it means there is an increasing as big as $136.7 \%$, on second mix for freeness level is 0.45 turn in 1.14 it means there is an increasing as big as 153,3\%, and third mix for internal bonding from 0.55 turn to 1.15 it is means there is an increasing as big as $109 \%$.
\end{abstract}

Keywords : mixture experiment; consistency; freeness; internal bonding

\footnotetext{
${ }^{*}$ Penulis Korespondensi. email: johnson_saragih@yahoo.com
} 


\section{Pendahuluan}

Kertas adalah bahan yang tipis dan rata, yang dihasilkan dengan kompresi serat yang berasal dari pulp.Serat yang digunakan biasanya adalah alami, dan mengandung selulosa dan hemiselulosa. Pada umumnya kertas digunakan sebagai alat tulis menulis tetapi sejalan dengan perkembangan zaman maka kebutuhan kertas hampir merambah didalam seluruh aspek kehidupan.Menurut kementrian perindustrian produksi kertas pada tahun 2013 adalah sebesar 13.000.000,- ton pertahun dan diperkirakan untuk tahun tahun mendatang terus meningkat sesuai dengan kebutuhan. Hal ini disebabkan karena adanya pola konsumsi kertas penduduk Indonesia yang berubah, kertas bukan saja digunakan sebagai alat tulis menulis tetapi juga sudah merambah kepada kebutuhan rumah tangga seperti penggunan kertas tissue ,karton dll.Menurut Wahana Lingkungan Hidup Indonesia atau WALHI (2009), peningkatan konsumsi kertas penduduk Indonesia sudah terlihat meningkat sejak tahun 1989, pada tahun 1989 konsumsi kertas penduduk Indonesia hanya sekitar $5,7 \mathrm{~kg} / \mathrm{kapita} /$ tahun meningkat menjadi 6,3 $\mathrm{kg} / \mathrm{kapita} /$ tahun pada tahun 1990 dan meningkat lagi menjadi 7,0 kg/kapita/tahun pada tahun1991.dan pada tahun 2009 meningkat menjadi 26kg/kapita/thn (Dirjen agro industri,2009).Kertas pada umumnya terbuat dari kayu yang dipotong potong, dengan ukuran kecil kecil, yang biasanya disebut dengan chip dimesin chipping, kemudian chip dimasukkan kemesin digester yang berfungsi untuk memisahkan kayu dengan lignin. Hasil dari mesin ini disebut dengan buburan kertas yang diproses kemudian menjadi kertas di paper machine.Buburan kertas atau yang biasa disebut dengan pulp adalah merupakan campuran dari chip, air dan bahan kimia lainnya seperti rosin, aluminium sulfat $\left(\mathrm{Al}_{2}(\mathrm{SO} 4)_{3}\right)$, komposisi buburan kertas ini diduga dapat meningkatkan kualitas kertas. Seperti diketahui bahwa kualitas dapat diartikan kesesuaian dengan standard yang telah ditentukan atau yang menurut Joseph M Juran (1954) quality is fitness for use, sedangkan indikator kualitas kertas ditentukan dengan tingkat ketegangan kertas atau yang disebut tensile strength, kelicinan kertas dan tingkat gramature .Parameter parameter ini dapat tercapai dengan baik apabila komposisi campuran pada kertas terkondisi dalam keadaan optimal.Sedangkan yang terjadi selama ini di perusahaan hanyalah bersifat try and errors .Mixture experiment adalah salah satu metoda yang dapat dipakai untuk memenuhi kebutuhan ini, dimana setiap elemen campuran dapat dirandomisasi dengan software minitab versi 16 , kemudian randomisasi tersebut dapat dipakai sebagai tolak ukur titik titik percobaan yang dapat digunakan pada laboratorium.dengan demikian komposisi buburan kertas yang dinginkan dapat optimal. Oleh karena itu yang menjadi tujuan pada penelitian ini adalah: Menentukan komposisi buburan kertas ( kraft liner $150 \mathrm{gsm}$ ) yang optimal dengan metoda mixture experiment, guna meningkatkan kualitas kertas yang dihasilkan.

\section{Mixture experiments}

Douglas C.Montgomery (2009), menyatakan bahwa mixture experiment adalah merupakan bagian khusus dari Response Surface Methodology, dimana faktor faktor yang berpengaruh selalu berjumlah sama dengan satu, secara umum persamaan matematis dari Mixture experiment dapat dimodelkan sebagai :

$\mathrm{y}=\mathrm{f}\left(\mathrm{x}_{1}, \mathrm{x}_{2}, \mathrm{x}_{3}, \mathrm{x}_{4} \ldots \ldots \ldots \mathrm{x}_{\mathrm{p}}\right)$ dengan $\mathrm{x}_{1}+\mathrm{x}_{2}+\mathrm{x}_{3}+$ $\mathrm{x}_{4} \ldots \ldots \mathrm{x}_{\mathrm{p}}=1$, dimana $\mathrm{y}$ : menyatakan variabel yang dipengaruhi atau biasa disebut sebagai variabel response, sedangkan $\mathrm{x}_{1}, \mathrm{x}_{2}, \mathrm{x}_{3} \ldots \ldots \ldots \mathrm{x}_{\mathrm{p}}$ adalah variabel yang mempengaruhi, berupa komposisi komposisi campuran.Jika $\mathrm{p}=2$ maka $\mathrm{x}_{1}+\mathrm{x}_{2}=1$ dapat digambarkan dalam sistem koordinat kartesius berupa bidang datar, dimana nilai $\mathrm{x}_{1}$ dan $\mathrm{x}_{2}$ dibatasi antara 0 dan $1,\left(0 \leq x_{1}, x_{2} \leq 1\right)$, sedangkan jika $\mathrm{p}=3$ maka $\mathrm{x}_{1}+\mathrm{x}_{2}+\mathrm{x}_{3}=1$, dapat digambarkan pada dimensi 3 berupa kubus dengan nilai $\mathrm{x}_{1}, \mathrm{x}_{3}$ dan $\mathrm{x}_{3}$ dapat bergerak dari 0 hingga 1 atau $\left(0 \leq x_{1}, x_{2}, x_{3} \leq 1\right)$

\section{Simplex lattice design}

Perancangan simplex lattice, digunakan symbol $\mathrm{A}\{\mathrm{p}, \mathrm{m}\}$ dimana $\mathbf{p}$ menujukkan komposisi yang disetting, sedangkan $\mathbf{m}$ menunjukkan proporsi pembagi dari setiap komponen dan banyaknya proporsi adalah sebe-

sar $\mathrm{m}+1$, sedangkan komposisi tersebut dapat dirancang sebanyak $\mathrm{N}$, dimana $\mathrm{N}$ dapat ditunjukkan dengan formula sebagai berikut :

$$
N=\frac{(p+m-1) !}{m !(p-1) !}, x_{i}=0, \frac{1}{m}, \frac{2}{m} \cdot \cdot 1, i=1,2, p:(1)
$$

Misalkan akan dirangcang simplex lattice dengan symbol $A\{3,2\}=A\{p, m\}$ berarti $p=3$ dan $m=2$ akan diperoleh titik perancangan adalah sebagai berikut:

$$
\begin{aligned}
& \left(x_{1}, x_{2}, x_{3}\right)=(1,0,0),(0,1,0),(0,0,1),\left(\frac{1}{2}, \frac{1}{2}, 0\right), \\
& \left(\frac{1}{2}, 0, \frac{1}{2}\right),\left(0, \frac{1}{2}, \frac{1}{2}\right) \cdots \cdots \cdots(2) \\
& N=\frac{(3+2-1) !}{2 !(3-1) !}=\frac{4 !}{2 ! 2 !}=\frac{1 \cdot 2 \cdot 3 \cdot 4}{1.2,1.2}=6
\end{aligned}
$$

Dimana $\mathrm{N}$ menunjukkan menunjukkan banyaknya rancangan seperti pada persamaan 2 Simplex centroid design

Perancangan simplex centroid untuk p akan diperoleh $2^{\mathrm{p}}-1$, misal $\mathrm{p}=3$ maka akan diperoleh $2^{3}-1=7$ titik percobaan yaitu: 


$$
\begin{aligned}
& \left(x_{1}, x_{2}, x_{3}\right)=(1,0,0),(0,1,0),(0,0,1),\left(\frac{1}{2}, \frac{1}{2}, 0\right) \\
& \left(\frac{1}{2}, 0, \frac{1}{2}\right),\left(0, \frac{1}{2}, \frac{1}{2}\right),\left(\frac{1}{3}, \frac{1}{3}, \frac{1}{3}\right)
\end{aligned}
$$

Sedangkan formulasi ekspektasi dari setiap variabel response dalam bentuk linier adalah sebagai berikut:

$$
E(y)=\sum_{i=1}^{p} \beta_{i} x_{i}+\sum \sum_{i<j}^{p} \beta_{i j} x_{i} x_{j}
$$

Sedangkan persamaan ekspektasi dalam bentuk full cubic:

$$
\begin{aligned}
& E(y)=\sum_{i=1}^{p} \beta_{i} x_{i}+\sum \sum_{i<j}^{p} \beta_{i j} x_{i} x_{j}+\sum \sum_{i<j}^{p} \delta_{i j} x_{i} x_{j}\left(x_{i}-x_{j}\right) \\
& +\sum \sum_{i<j<k} \sum \beta_{i j k} x_{i} x_{j} x_{k} \cdots \cdots \cdots \cdot(4)
\end{aligned}
$$

Dan persamaan ekspektasi dalam bentuk special cubic adalah :

$$
\begin{aligned}
& E(y)=\sum_{i=1}^{p} \beta_{i} x_{i}+\sum \sum_{i<j}^{p} \beta_{i j} x_{i} x_{j}+ \\
& \sum \sum_{i<j<k} \sum \beta_{i j k} x_{i} x_{j} x_{k} \cdots \cdots(5)
\end{aligned}
$$

\section{Metodologi penelitian}

Seperti yang telah dijelaskan pada pendahuluan bahwa untuk menentukan komposisi optimal pada campuran buburan kertas adalah dengan membangkitkan randomisasi titik percobaan dengan menggunakan software minitab versi 16.dimana percobaan pertama adalah merupakan antara waste paper ,pulp dan air,kedua adalah terdiri dari campuran pertama,rosin dan lauminium sulfat dan ketiga adalah campuran kedua dan starch. Adapun langkah langkah yang akan ditentukan pada penelitian ini adalah:

1. Menentukan komposisi campuran pertama yang terdiri dari waste paper, pulp (NUKP) dan air.

2. Menentukan komposisi camputan kedua yang terdiri dari campuran pertama, rosin dan Almunium sulfat $\left(\mathrm{Al}_{2}\left(\mathrm{SO}_{4}\right)_{3}\right)$.

3. Menentukan komposisi campuran tiga dengan campuran kedua ditambah Starch

4. Menentukan campuran optimum dari masing masing komponen

5. Mencari hubungan antara variabel respon dengan komponen komposisi campuran optimal secara matematis

6. Membandingkan kapabilitas proses antara produk yang bersifat trial and error dengan mixture experiment.

Sedangkan flow chart dapat dilihat seperti pada gambar 1, sebagai salah satu contoh proses pembuatan campuran satu yang optimum.

Jurnal Teknik Industri, Vol. X, No. 3, September 2015

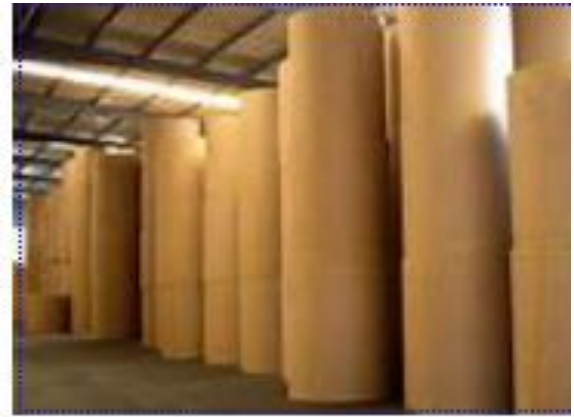

Gambar 2. kertas kraft liner $150 \mathrm{gsm}$

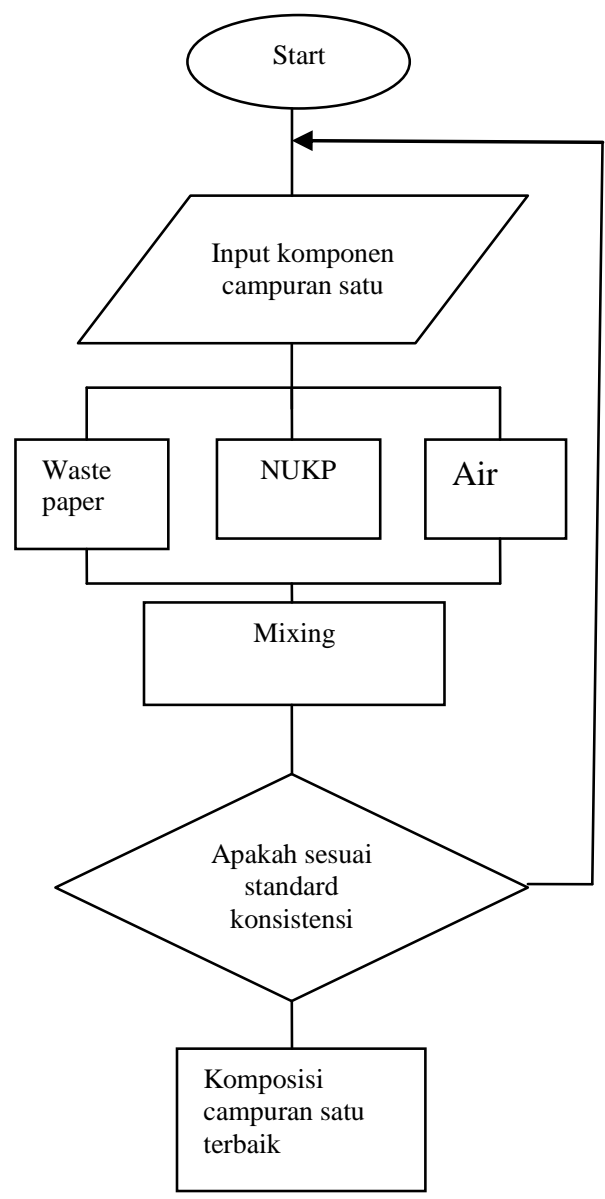

Gambar 1. Flow chart campuran satu

\section{Hasil dan Pembahasan}

Pada penelitian ini, kertas yang diteliti adalah kertas kraft liner 150 gsm, gambar 2.

Adapun proses pembuatan kraft liner 150 gsm dapat dibagi menjadi beberapa tahapan sebagai berikut:

1. Proses pembuatan buburan kertas:

Siapkan waste paper sebanyak 425 gram dan pulp (NUKP) sebanyak 50 gram terlebih dahulu, kemudian direndam selama 30 menit, lalu diblender selama 20 menit, kemudian dicampur air sebanyak 25 gram air sehingga diperoleh buburan kertas sebanyak 500 gram. 
2. Proses pengukuran konsistensi:

Buburan kertas tersebut, kemudian dicek kadar air-nya ( konsistensinya) dengan menggunakan alat ukur timbangan digital dimana batasan konsistenya adalah berkisar antara 3.5-4.5\%, sedangkan formulasi dari nilai konsistensi adalah

$$
C=\frac{A}{B} x 100 \%
$$

$\mathrm{C}=$ Konsistensi dalam persen $(\%)$

$\mathrm{A}=$ Berat basah buburan kertas (gr)

$\mathrm{B}=$ Berat kering buburan kertas (gr)

3. Proses pencucian buburan kertas

Pencucian buburan kertas dilakukan dengan menambahkan air pada buburan lalu dicuci kemudian disaring untuk memisahkan kotoran kotoran yang tersisa.

4. Proses penggilingan buburan kertas.

Setelah buburan kertas tersebut dicuci kemudian ditambah dengan bahan kimia lain seperti rosin sebanyak 30 gram dan aluminium sulfat sebanyak 15 gram, kemudian diblender selama 40 menit, lalu disaring kemudian hasil saringan-nya disimpan dalam satu tempat.

5. Proses pengukuran derajat giling (freeness)

Hasil dari buburan kertas yang disimpan tadi,diambil sebanyak 10 gr kemudian dicampur dengan air sebanyak $1000 \mathrm{ml}$ lalu dituangkan kedalam tabung gelas, hasil campuran tersebut diukur dengan alat Canadian Freeness Tester dengan batasan pengukuran 300-400 ml CSF

6. Proses pembentukan lembaran kertas

Setelah dilakukan uji freeness pada buburan kertas selanjutnya dilakukan pembentukan lembaran kertas dengan cara memasukkan buburan kertas kedalam bingkai cetakan ( frame), kemudian lembaran kertas tersebut di press, lembaran kertas tersebut dikeringkan selama kurang lebih 2 atau 3 jam, maka terbentuklah lembaran lembaran kertas.

7. Pengujian Cobb size.

Pengujian cobb size bertujuan untuk mengetahui berapa banyaknya air yang diserap kertas dalam waktu 120 detik, adapun batasan cobb size adalah $145-155 \mathrm{gr} / \mathrm{m}^{2} / 120 \mathrm{sec}$, dan alat yang digunakan untuk pengukuran cob size adalah cobb size tester.

8. Pegujian internal bonding.
Pengujian internal bonding pada kertas adalah untuk mengetahui seberapa kuat ikatan serat pada kertas atau dengan perkataan lain untuk menguji kehomogenannya, adapun batasan yang diizinkan adalah sebesar $290-310 \mathrm{~J} / \mathrm{m}^{2}$.

\section{Formulasi model umum}

Dari uraian diatas, maka kualitas kertas kraft liner 150 gsm dapat diformulasikan secara umum adalah sebagai berikut:

$$
\text { Kkkl150gsm=f(k,f,cb,ib) }
$$

dimana :

Kkkl150gsm : Menyatakan kualitas kertas kraft liner $150 \mathrm{gsm}$.

$$
\begin{aligned}
& \mathrm{k} \text { : Menyatakan tingkat konsistensi } \\
& \mathrm{f}: \text { Menyatakan tingkat freeness } \\
& \mathrm{cb} \text { : Menyatakan tingkat cob size } \\
& \mathrm{ib} \text { : Menyatakan internal bonding }
\end{aligned}
$$

Sub model umum satu:

$$
\begin{aligned}
& \mathrm{k}=\mathrm{f}(\mathrm{WP}, \mathrm{VP}, \mathrm{A}) \\
& \mathrm{k}: \text { Menyatakan konsitensi } \\
& \text { WP: Menyatakan Waste Paper } \\
& \text { VP: Virgin Pulp ( NUKP) } \\
& \text { A : Air }
\end{aligned}
$$

Sub model umum dua:

$\mathrm{f}$ atau $\mathrm{Cb}=\mathrm{g}(\mathrm{R}, \mathrm{AS}, \mathrm{Csatu})$

f :Menyatakan freenes

$\mathrm{cb}$ :Menyatakan cob size

$\mathrm{R}$ :Menyatakan rosin

AS :Menyatakan Aluminium Sulfat

Csatu: Menyatakan campuran satu

Sub model tiga:

$$
\begin{aligned}
& \mathrm{Ib}=\mathrm{h}(\mathrm{S}, \text { Csatu,Cdua) } \\
& \mathrm{Ib} \quad \text { : Menyatakan internal bonding } \\
& \text { Csatu : Menyatakan campuran satu } \\
& \text { Cdua : Menyatakan campuran dua }
\end{aligned}
$$

\section{Pengukuran konsistensi}

Untuk mengetahui sampai sejauh mana kapabilitas proses pada campuran yang bersifat try and error maka dilakukan pengukuran konsistensi kertas kraft liner 150 gsm pada perusahaan, Pengumpulan data yang diperoleh dari tanggal 19-29 Januari 2009. Adapun hasil pengolahan yang diplot pada peta kendali X-MR adalah sebagai berikut: 
Gambar 3. Peta kendali Xbar-MR konsistensi

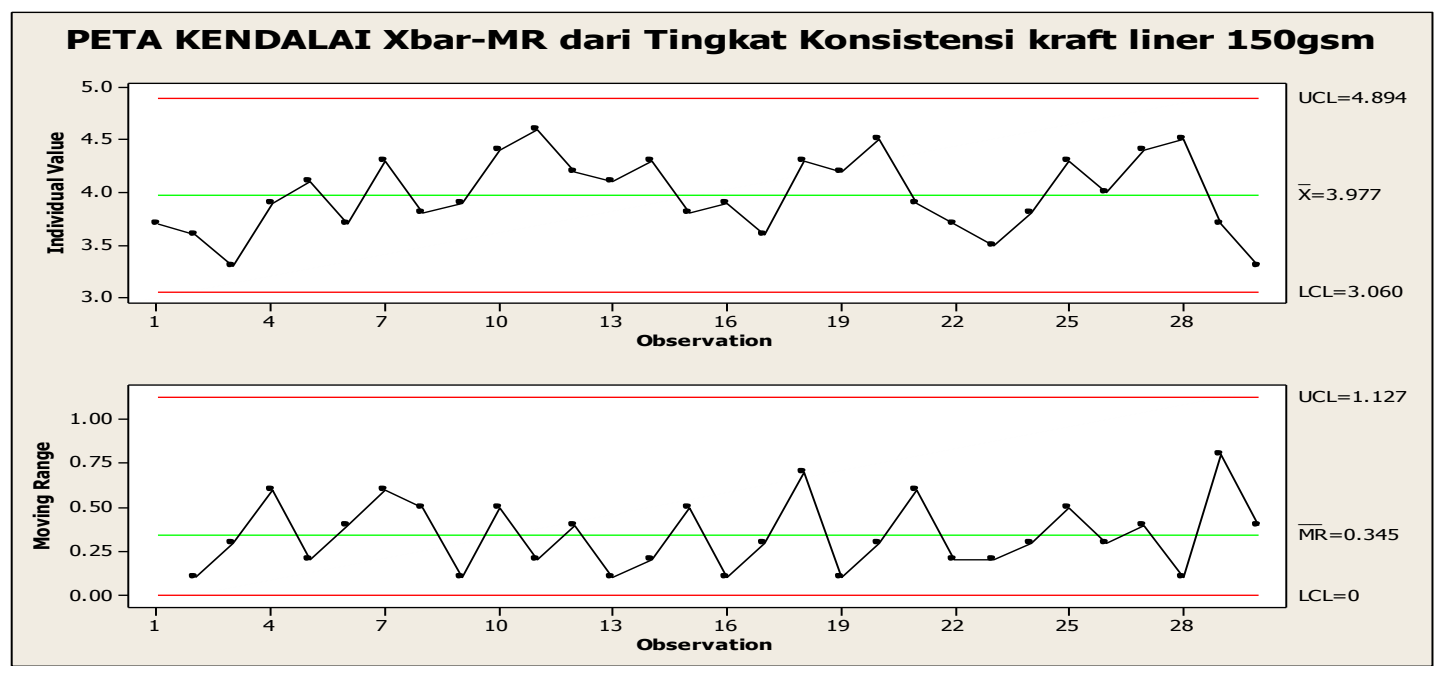

Gambar 4. Pola data konsistensi

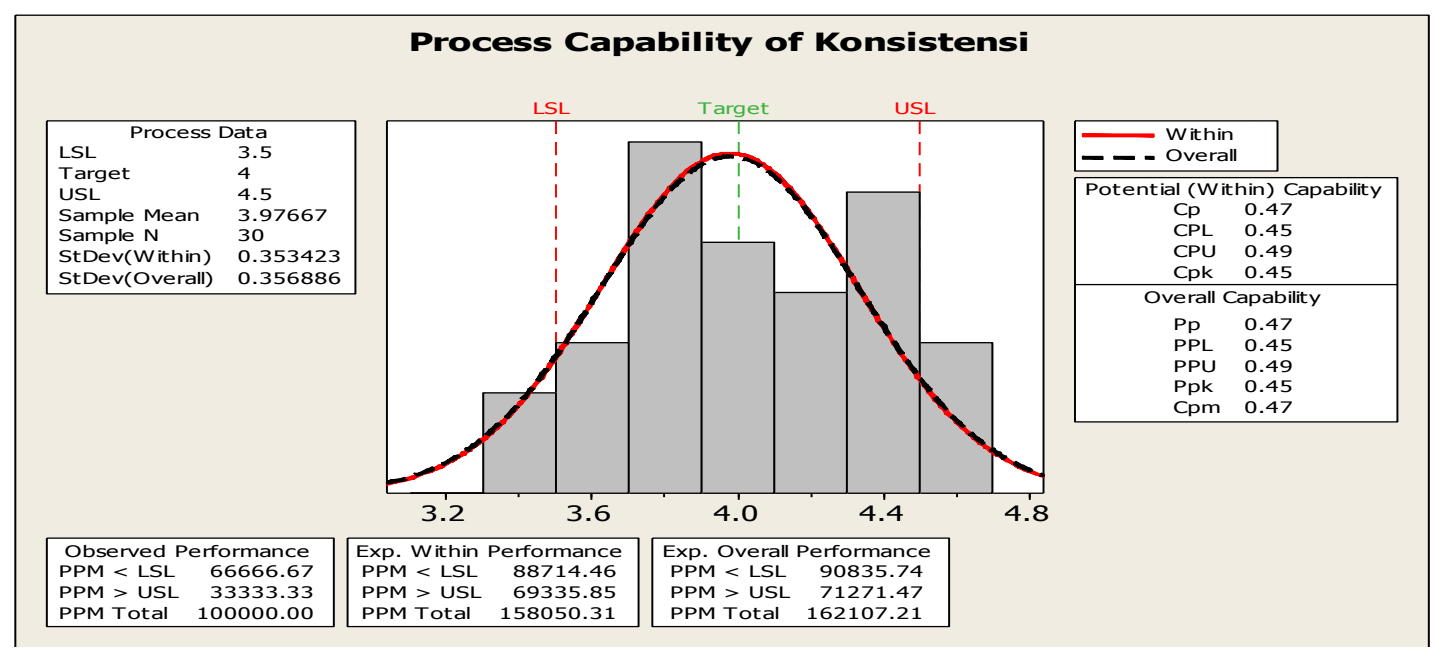

Gambar 5. Peta kendali Xbar-MR Freeness

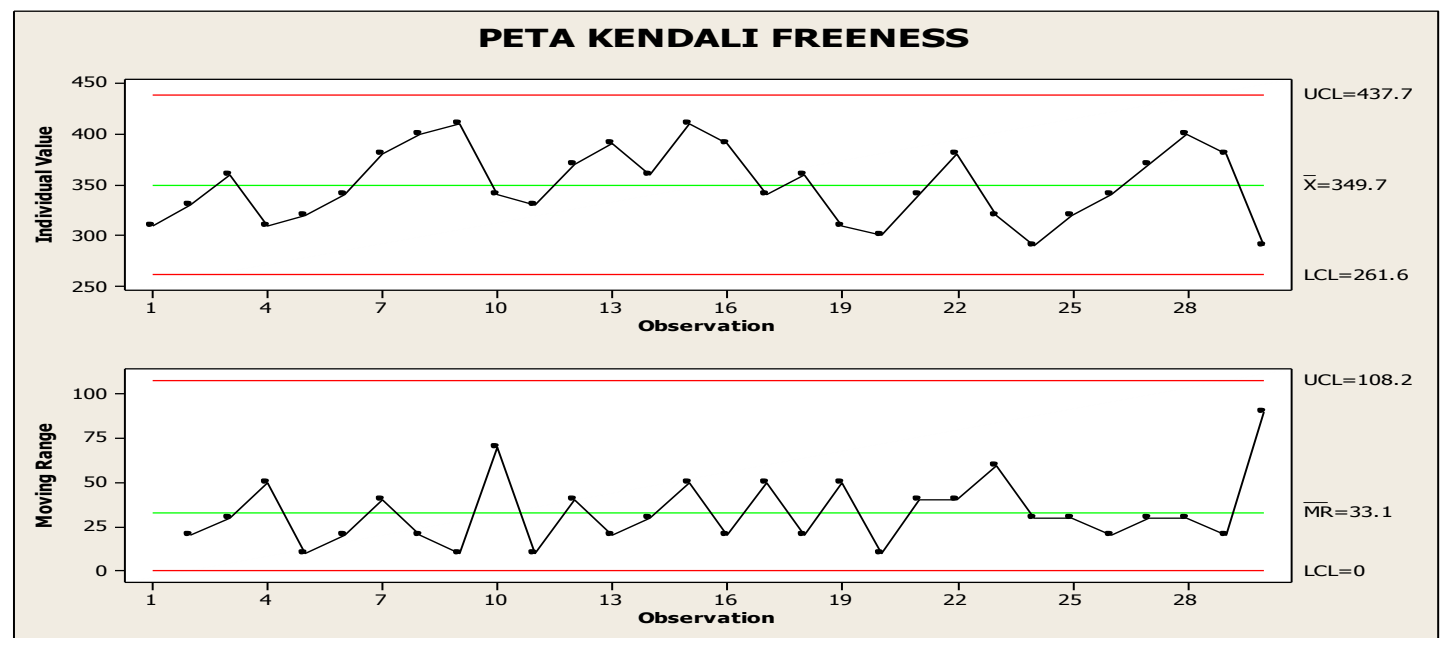


Gambar 6. Pola data freeness

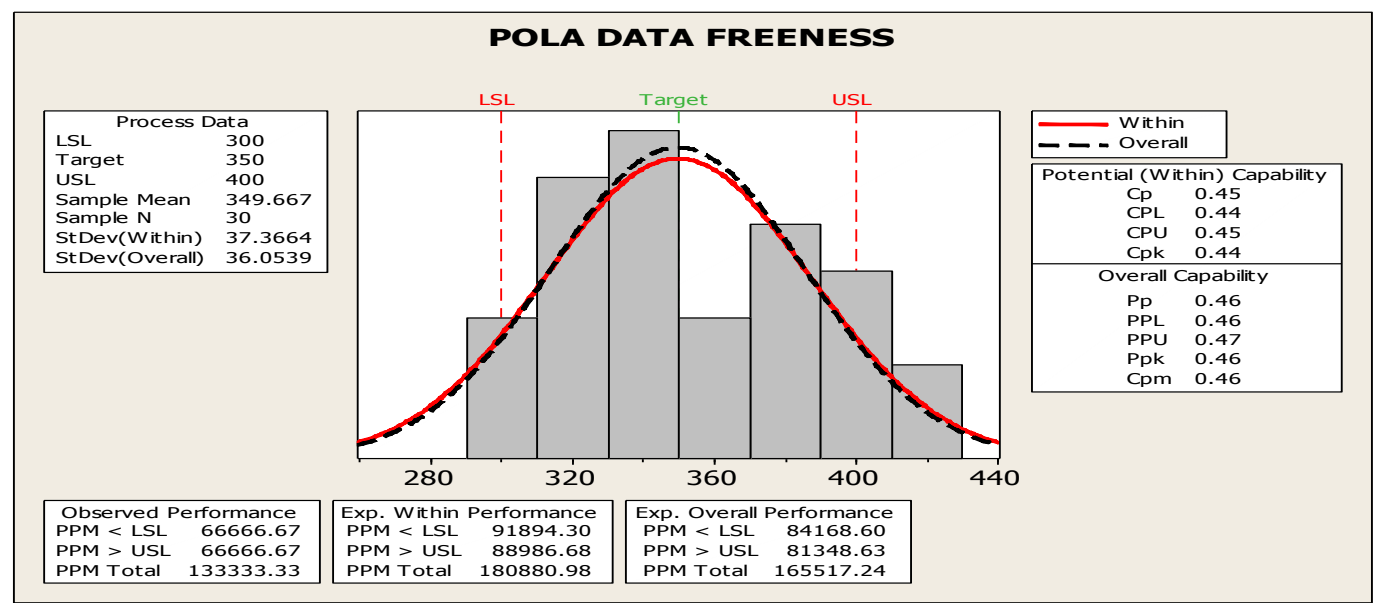

Gambar 7. Peta kendali cobb size

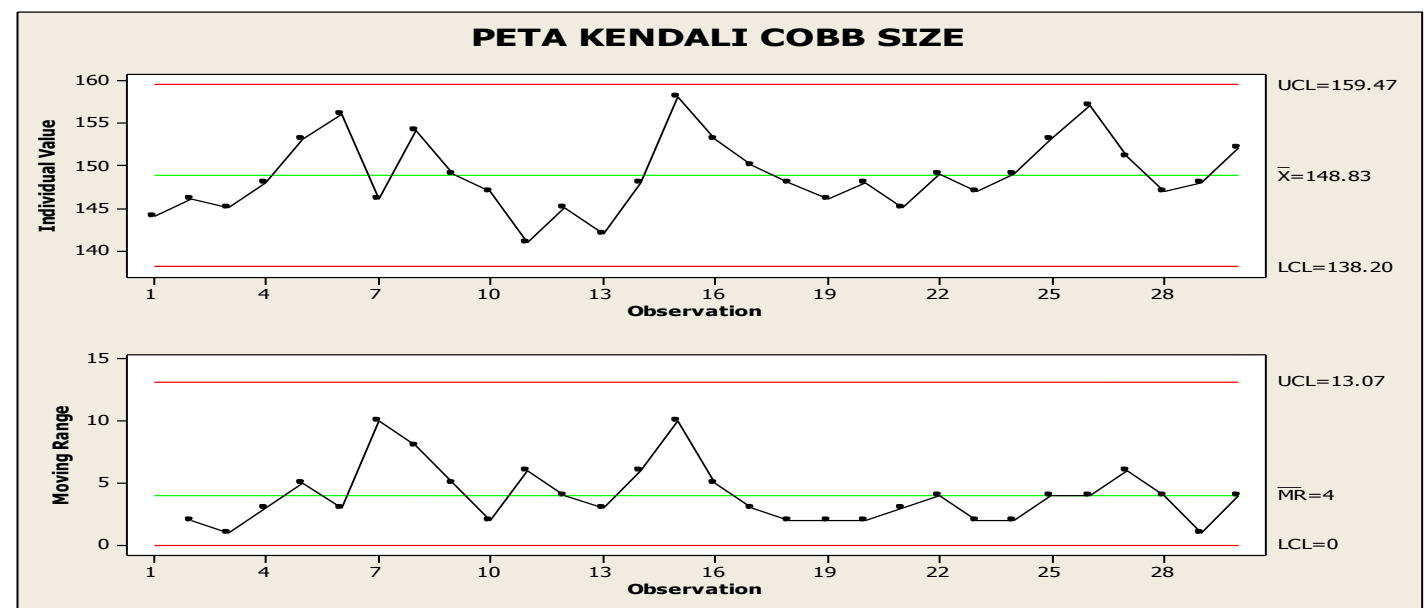

Gambar 8. Pola data cobb size

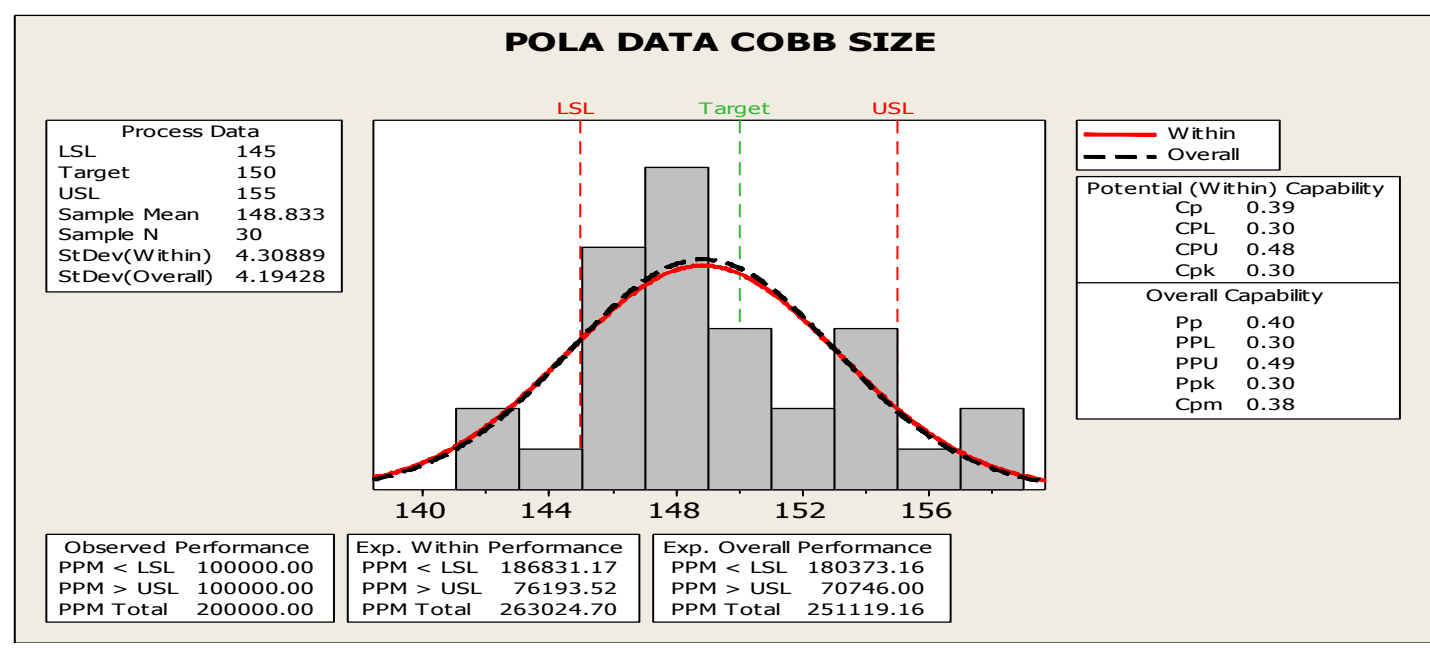


Gambar 9. Peta kendali Internal Bonding

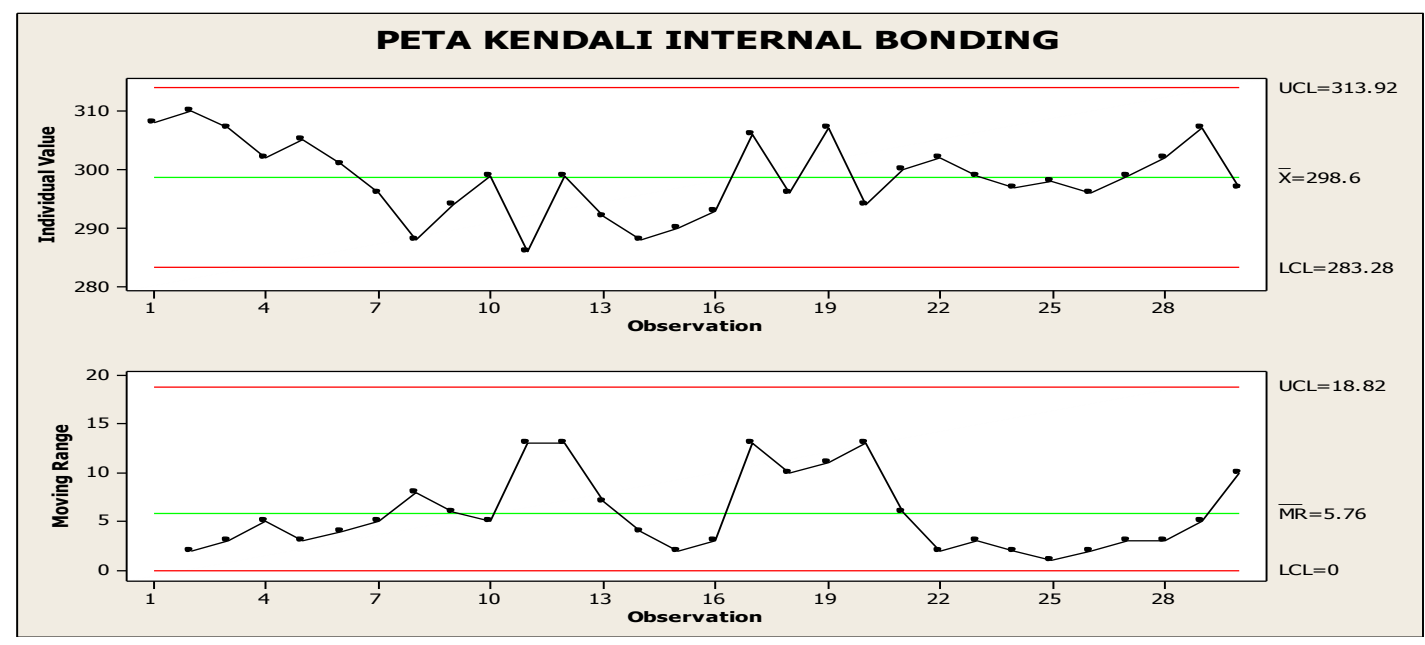

Gambar 10. Pola data Internal Bonding

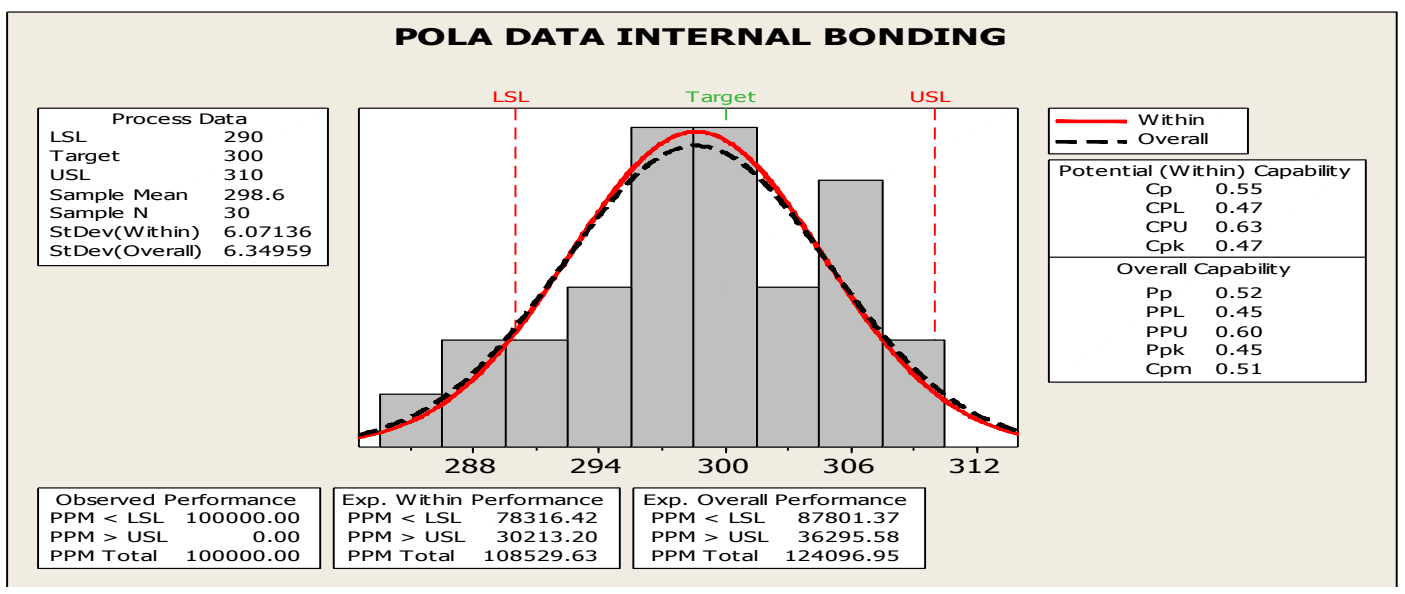

Jika kita perhatikan pola data yang ada pada gambar 3 dan 4, ternyata proses pengukuran pada konsistensi masih berada pada batas control yang ada, tetapi kapabilitas prosesnya $\mathrm{Cp}=0.47$ dan $\mathrm{Cpk}=0.45<1$, masih jauh dari yang diharapkan oleh karena itu perlu dilakukan perbaikan.

\section{Pengukuran Freeness}

Pengukuran Freeness dilakukan pada campuran adalah untuk mengetahui sampai sejauh mana kehalusan buburan kertas yang diperoleh yang dapat dinyatakan dengan derajad giling satuannya $\mathrm{ml}$ CSF, pada campuran buburan kertas yang bersifat trial and error.Adapun data data yang diperoleh berdasarkan pengumpulan data dari tanggal 19-29 pada gambar 5 .

Seperti terlihat pada peta kendali dan pola data pada gambar 5 dan 6, ternyata bahwa masih dalam batas control yang telah ditentukan, tetapi kapabilitas prosesnya masih rendah yakni $\mathrm{Cp}=0.45$ dan $\mathrm{Cpk}=0.44<1$ masih jauh dari yang diharapkan oleh karena itu perlu dilakukan perbaikan.

Jurnal Teknik Industri, Vol. X, No. 3, September 2015

\section{Pengkuran Cobb size}

Pengukuran Cobb size dilakukan untuk mengetahui sampai sejauh mana daya serap kertas dalam waktu 120 detik.Adapun data yang dikumpulkan pada tanggal 19-29 Januari 2009, seperti yang terlihat pada gambar 7 dan 8 .

Dan Jika kita melihat penyebaran data pada peta kendali cobb size, masih pada batas kendali tetapi $\mathrm{Cp}$ $=0.39$ dan $\mathrm{Cpk}=0.33<1$ masih jauh dari yang diharapkan, sehingga perlu diperbaiki.

\section{Pengukuran Internal Bonding}

Pengukuran pada Internal Bonding adalah untuk mengetahui seberapa kuat ikatan kertas dengan standard yang telah ditentukan perusahaan adalah 290-310 (J/m $\left.{ }^{2}\right)$ dan targetnya adalah sebesar 300 $\left(\mathrm{J} / \mathrm{m}^{2}\right)$.Sedangkan hasil pengurannya dapat dilihat pada Gambar:9 dan 10.

Hasil pengukuran Internal Bonding pada Gambar 9 terlihat bahwa pola data masih pada batas control yang ada, tetapi kapabilitas proses $\mathrm{Cp}=0.55$ 
dan $\mathrm{Cpk}=0.47<1$ masih jauh dari yang diharapkan oleh karena itu masih perlu adanya perbaikan.

\section{Penentuan Campuran Satu}

Penentuan campuran satu berdasarkan brainstorming dengan perusahaan adalah terdiri dari Waste Paper, Pulp dan Air dimana batasan untuk Waste Air adalah berkisar diantara $85 \%$ s/d $6 \%$,Pulp dari $10 \%$ s/d $11 \%$ dan Air dari $4 \%$ s/d $5 \%$.Untuk jelasnya batasan tersebut dapat dilihat pada tabel 1 .

Tabel 1. Komponen Campuran Satu

\begin{tabular}{ccc}
\hline Komponen & Lower bound & Upper bound \\
\hline Waste Paper & 0.85 & 0.86 \\
Pulp & 0.1 & 0.11 \\
Air & 0.04 & 0.05 \\
\hline
\end{tabular}

Titik percobaan diperoleh dengan membangkitkan randomisasi pada minitab versi 16 dengan rumusan $\{p=3, q=2\} \quad$ sehingga diperoleh 14 titik percobaan.Indikator ini menjadi titik tolak yang dapat dilakukan pada pada percobaan di Laboratorium dimana setiap titik percobaan diukur tingkat konsistensinya.Adapun hasil randomisasi yang dilakukan dari tanggal 9-26 Februari 2009 dapat dilihat pada pada tabel 2, dibawah ini :

Tabel 2. Percobaan satu

\begin{tabular}{ccccc}
\hline \multirow{2}{*}{$\begin{array}{c}\text { Perco } \\
\text {-baan }\end{array}$} & \multicolumn{3}{c}{ Komponen } & $\begin{array}{c}\text { Konsis- } \\
\text { tensi }\end{array}$ \\
\cline { 2 - 4 } & W A & Pulp & Air & 3.8 \\
2 & 0.855 & 0.1 & 0.045 & 4.1 \\
3 & 0.853 & 0.103 & 0.043 & 4.2 \\
4 & 0.85 & 0.1 & 0.05 & 3.9 \\
5 & 0.85 & 0.105 & 0.045 & 3.8 \\
6 & 0.86 & 0.1 & 0.04 & 3.7 \\
7 & 0.855 & 0.105 & 0.04 & 3.7 \\
8 & 0.85 & 0.105 & 0.04 & 4.3 \\
9 & 0.855 & 0.1 & 0.05 & 3.8 \\
10 & 0.86 & 0.1 & 0.045 & 3.9 \\
11 & 0.85 & 0.11 & 0.04 & 3.8 \\
12 & 0.85 & 0.105 & 0.045 & 3.9 \\
13 & 0.853 & 0.103 & 0.043 & 4.0 \\
14 & 0.85 & 0.11 & 0.04 & 3.9 \\
\hline
\end{tabular}

Dari randomisasi diperoleh hasil dalam bentuk estimasi regresi adalah sebagai berikut:

Estimated Regression Coefficients for RONSISTENSI (pseus

$\begin{array}{lrrrrr}\text { Term } & \text { Coef } & \text { SE Coef } & \text { T } & \text { P } & \text { VIF } \\ \text { Waste Paper } & 3.8568 & 0.1436 & * & * & 1.599 \\ \text { Pulp } & 3.9568 & 0.1436 & * & * & 1.599 \\ \text { Air } & 3.8068 & 0.1436 & * & * & * 1.599 \\ \text { Waste Paper }{ }^{*} \text { Pulp } & -0.5364 & 1.6281 & -0.33 & 0.750 & 4.826 \\ \text { Waste Paper*Air } & -0.2364 & 1.6281 & -0.15 & 0.888 & 4.826 \\ \text { Pulp*Air } & 1.5636 & 1.6281 & 0.96 & 0.365 & 4.826\end{array}$

Jurnal Teknik Industri, Vol. X, No. 3, September 2015
Hasil tampilan dari estimasi regresi ini dapat direpresentasikan dalam bentuk persamaan matematis adalah sebagai berikut:

$\hat{y}_{k}=3.8568 x_{W P}+3.9568 x_{P}+3.8068 x_{A}$

$-0.5364 x_{W P} \cdot x_{P}-0.2364 x_{W P} \cdot x_{A}$

$+1.5653 x_{P} \cdot x_{A} \cdots \cdots \cdots \cdots \cdots \cdots \cdots(6)$

Dengan, $\mathrm{X}_{\mathrm{WP}}$ Menyatakan variabel waste paper $\mathrm{x}_{\mathrm{P}}$ : Menyatakan variabel pulp

$\mathrm{x}_{\mathrm{A}}$ : Menyatakan variabel air

dan jika persamaan (7) direpresentasikan dalam bentuk gambar dalam dimensi tiga dapat dilihat pada gambar 11 dan jika bidang lengkung tersebut diprojeksikan ke bidang dimensi dua maka hasilnya dapat dilihat pada gambar 12

Pada gambar 12, konsistensi terbesar yaitu sebesar lebih dari 4.2 terletak pada daerah hijau pekat sedangkan yang konsistensi lebih kecil dari 3.8 terletak pada daerah hijau muda, kosistensi ini berubah-ubah besarnya bersesuaian dengan warnanya.

Gambar 11. Surface plot

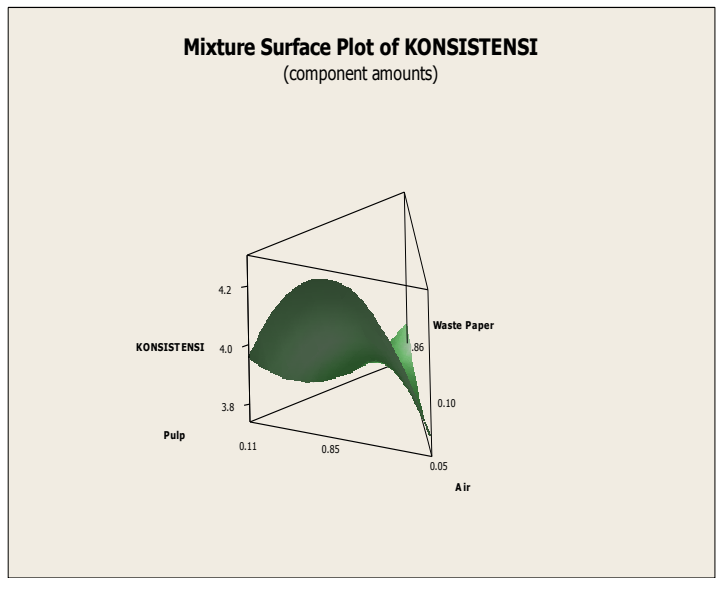

Gambar 12. Contour plot

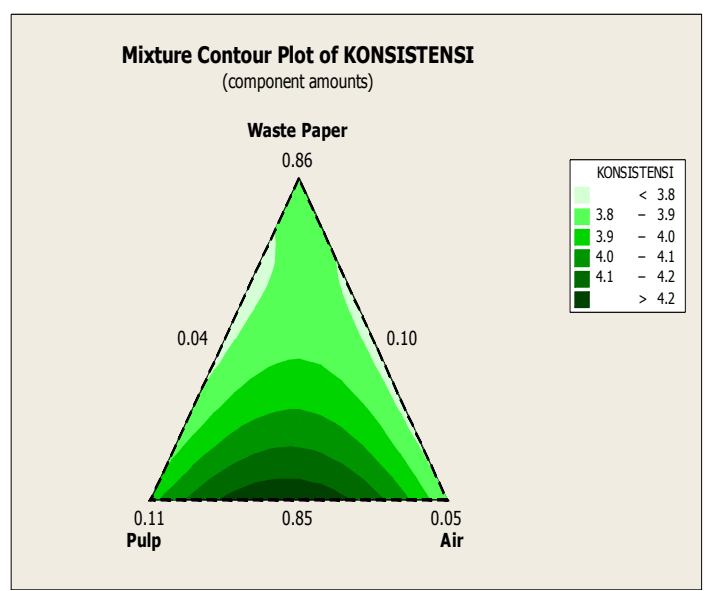




\section{Penentuan campuran dua}

Campuran dua terdiri dari bahan baku campuran satu, Rosin dan Aluminium sulfat. Ketiga bahan baku tersebut memiliki batasan minimum dan maksimum, adapun maksud digunakannya batasan ini adalah untuk memberikan peluang pencapaian optimal dari variable responnya yaitu tingkat freeness dan cob size. Dimana batasan tersebut dapat dilihat pada tabel 3

Tabel 3. Komponen campuran dua

\begin{tabular}{ccc}
\hline Komponen & Lower & Upper \\
\hline Campuran satu & 0.90 & 0.91 \\
Rosin & 0.06 & 0.07 \\
Aluminium sulfat & 0.03 & 0.04 \\
\hline
\end{tabular}

Untuk memperoleh titik percobaan, secara sama dilakukan dengan percobaan satu, adapun adapun titik percobaan tersebut dapat dilihat pada tabel 4

Tabel 4. Percobaan dua

\begin{tabular}{cccccc}
\hline Perco & \multicolumn{3}{c}{ Komponen } & $\begin{array}{c}\text { Free- } \\
\text { ness }\end{array}$ & $\begin{array}{c}\text { Cob } \\
\text { b- } \\
\text { baan }\end{array}$ \\
\cline { 2 - 5 } & C-satu & Rosin & A S & & \\
\hline 1 & 0.9 & 0.06 & 0.04 & 320 & 154 \\
2 & 0.905 & 0.065 & 0.03 & 360 & 153 \\
3 & 0.9 & 0.065 & 0.035 & 340 & 154 \\
4 & 0.91 & 0.06 & 0.03 & 370 & 141 \\
5 & 0.9 & 0.07 & 0.03 & 340 & 143 \\
6 & 0.9033 & 0.0633 & 0.033 & 350 & 149 \\
7 & 0.905 & 0.065 & 0.03 & 370 & 157 \\
$: 8$ & 0.905 & 0.06 & 0.035 & 370 & 150 \\
9 & 0.9 & 0.07 & 0.03 & 330 & 143 \\
10 & 0.9 & 0.065 & 0.035 & 340 & 155 \\
11 & 0.9 & 0.06 & 0.04 & 320 & 153 \\
12 & 0.91 & 0.06 & 0.03 & 360 & 141 \\
13 & 0.905 & 0.06 & 0.035 & 370 & 150 \\
14 & 0.903 & 0.063 & 0.033 & 350 & 149 \\
\hline
\end{tabular}

Adapun hasil estimasi persamaan regresi adalah sebagai berikut:

Estimated Regression Coefficients for Freeness (pseudocomponents)

$\begin{array}{lrrrrr}\text { Term } & \text { Coef } & \text { SE Coef } & \text { T } & \text { P } & \text { VIF } \\ \text { Campuran 1 } & 340.8 & 12.78 & * & * & 1.599 \\ \text { Rosin } & 365.8 & 12.78 & * & * & 1.599 \\ \text { Aluminium sulfat } & 345.8 & 12.78 & * & * & 1.599 \\ \text { Campuran 1*Rosin } & -200.0 & 144.94 & -1.38 & 0.205 & 4.826 \\ \text { Campuran 1*Aluminium sulfat } & 40.0 & 144.94 & 0.28 & 0.790 & 4.826 \\ \text { Rosin*Aluminium sulfat } & 130.0 & 144.94 & 0.90 & 0.396 & 4.826\end{array}$

Dalam bentuk persamaan model matematis dapat direpresentasikan sebagai berikut:

$$
\begin{aligned}
& \hat{y} k=340.8 x_{C s}+365.8 x_{R}+345.8 x_{A S} \\
& -200 x_{C s} \cdot x_{R}+40 x_{C s} \cdot x_{A S}+130 x_{R} \cdot x_{A S}
\end{aligned}
$$

Jurnal Teknik Industri, Vol. X, No. 3, September 2015
Dimana :

$\mathrm{y}_{\mathrm{k}}$ :Menyatakan freeness

$\mathrm{x}_{\mathrm{Cs}}$ :Menyatakan variabel campuran satu

$\mathrm{x}_{\mathrm{R}}$ :Menyatakan variabel Rosin

$\mathrm{x}_{\mathrm{AS}}$ :Menyatakan variabel Aluminium sulfat

Sedangkan estimasi persamaan regressi untuk variabel respon cobb size adalah sebagai berikut:

Es imated Regression Coefficients for Cobb size (pseudocomponents)

$\begin{array}{lrrrrr}\text { Term } & \text { Coef } & \text { SE Coef } & \text { T } & \text { P } & \text { VIF } \\ \text { Campuran satu } & 151.64 & 4.000 & * & * & 1.599 \\ \text { Rosin } & 151.14 & 4.000 & * & * & 1.599 \\ \text { Aluminium sulfat } & 148.64 & 4.000 & * & * & 1.599 \\ \text { Campuran satu*Rosin } & -25.73 & 45.359 & -0.57 & 0.586 & 4.826 \\ \text { Campuran satu*Aluminium sulfat } & 61.27 & 45.359 & 1.35 & 0.214 & 4.826 \\ \text { Rosin*Aluminium sulfat } & -55.73 & 45.359 & -1.23 & 0.254 & 4.826\end{array}$

Dalam bentuk persamaan matematis adalah sebagai berikut:

$\hat{y}_{k}=151.64 x_{C s}+151.14 x_{R}+148.64 x_{A S}$

$-25 x_{C s} \cdot x_{R}+61.27 x_{C s} \cdot x_{A S}$

$-55.73 x_{R} \cdot x_{A S}$

Dengan:

$\mathrm{y}_{\mathrm{k}}$ : Menyatakan variabel respon cobb size

$\mathrm{x}_{\mathrm{Cs}}$ : Menyatakan variabel campuran satu

$\mathrm{x}_{\mathrm{R}}$ : Menyatakan variabel respon rosin

$\mathrm{x}_{\mathrm{AS}}$ : Menyatakan variabel aluminium sulfat

Untuk melihat hubungan antara komposisi campuran dua, secara grafis ditunjukkan pada grafik trace plot, gambar 13.

Gambar 13. Grafik trace plot

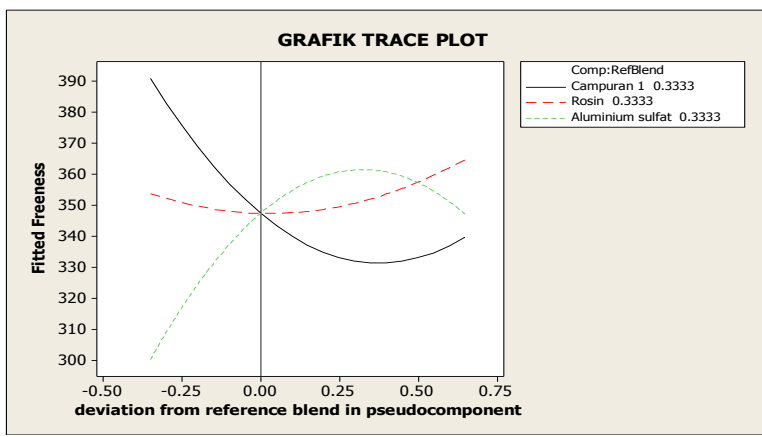

Adapun interpretasi dari campuran dua tersebut adalah: Apabila proporsi campuran dua meningkat maka Aluminium sulfat akan meningkat dan akan menurun pada proporsi sekitar 0.55 sedangkan rosin secara signifikan akan meningkat terus, dan campuran satu akan menurun tetapi akan meningkat kembali pada proporsi sekitar 0.55 .

\section{Penentuan campuran tiga}

Untuk percobaan campuran tiga ini dilakukan sebanyak 500 gr, pertitik percobaan, dimana komponen campuran terdiri dari campuran dua dan Starch. Dengan batas minimum sebesar 0.92 dan 
batas maksimum 0.93 untuk campuran dua, sedangkan untuk starch batas minimum sebesar 0.07 dan maksimum 0.08 , adapun batasan komponen tersebut dapat dilihat pada tabel 4 .

Tabel 4. Komponen campuran tiga

\begin{tabular}{lcc}
\hline Komponen & Lower & Upper \\
\hline Campuran dua & 0.92 & 0.93 \\
Starch & 0.07 & 0.08 \\
\hline Setelah dilakukan randomisasi titik titik & percoban
\end{tabular}

Setelah dilakukan randomisasi titik titik percobaan untuk percobaan campuran tiga dengan rumusan $\mathrm{A}\{\mathrm{p}=2, \mathrm{q}=2\}$, maka dapat diperoleh sebanyak 6 titik percobaan yang dapat dilihat pada tabel 5

Tabel 5. Percbaan campuran tiga

\begin{tabular}{cccc}
\hline \multirow{2}{*}{ Percobaan } & \multicolumn{2}{c}{ Komponen } & Internal \\
\cline { 2 - 3 } & Camp-dua & Starch & Bonding \\
\hline 1 & 0.930 & 0.070 & 297 \\
2 & 0.925 & 0.075 & 299 \\
3 & 0.930 & 0.070 & 298 \\
4 & 0.920 & 0.080 & 307 \\
5 & 0.920 & 0.080 & 306 \\
6 & 0.925 & 0.075 & 300 \\
\hline
\end{tabular}

Adapun hasil estimasi persamaan regresi linier dapat dilihat pada tabel 6, kemudian hasil ini dapat diinterpretasikan dalan bentuk persamaan matematis pada persamaan (10)

Tabel 6. Esimasi koefisien regressi

$$
\begin{array}{lrrrrr}
\text { Estimated Regression Coefficients for Internal Bonding (ps } \\
\text { Term } & \text { Coef } & \text { SE Coef } & \text { T } & \text { P } & \text { VIF } \\
\text { Campuran dua } & 288.50 & 6.198 & * & * & 1.250 \\
\text { Starch } & 303.00 & 6.198 & * & * & 1.250 \\
\text { Campuran dua*Starch } & 29.00 & 30.364 & 0.96 & 0.410 & 1.500 \\
& & & & &
\end{array}
$$

Sedangkan komposisi optimum yang dicapai dari ketiga percobaan tersebut dapat dilihat pada tabel 7 .

Tabel 7. Komposisi optimal

\begin{tabular}{llcc}
\hline No & Bahan baku & Komp (\%) & Berat (gr) \\
& & & \\
\hline 1 & Waste Paper & 71.23 & 356.15 \\
2 & Pulp & 8.75 & 43.55 \\
3 & Air & 3.54 & 17,7 \\
4 & Rosin & 5.7 & 28.5 \\
5 & Aluminium Sulfat & 3.29 & 16.4 \\
6 & Starch & 7.55 & 37.75 \\
& $\quad$ Total & $100 \%$ & 500 \\
\hline
\end{tabular}

Berdasarkan komposisi yang optimal yang telah dicapai pada tabel , maka campuran ini dilakukan pengukuran kembali terhadap kapabiliats proses untuk tingkat konsitensi, freeness dan internal bonding, pengukuran dilaksanakan pada tanggal 1019 Maret 2009. Adapun hasil dari kapabilitas proses untuk tingkat konsistensi adalah sebesar 1.11,tingkat freenesss 1.14 dan Internal bonding 1.15 yang berarti masing masing mengalami peningkatan berturut-turut untuk tingkat konsistensi sebesar 136.7\%,tingkat feeness sebesar $153.3 \%$ dan internal bonding sebesar $109 \%$.

\section{Kesimpulan}

Setelah dilakukan pengumpulan dan pengolahan data yang disertai percobaan pada Laboraorium, maka kesimpulan yang dapat ditarik pada penelitian ini adalah, bahwa komposisi optimal campuran buburan kertas adalah komponen $\mathrm{W}$ aste Paper sebesar $71.23 \%$ (356.15gr),Pulp (NUKP) sebesar $8.72 \%$ (43.55gr), Air sebesar 3.54\% (17.7 gr), Rosin sebesar $5.7 \%$ (28.5 gr), Aluminium Sulfat sebesar $3.29 \%$ (16.4 gr) dan Starch sebesar $7.55 \%$ (37.75 gr), komposisi campuran berhasil meningkatkan kualitas kertas, hal ini terlihat, setelah dilakukan perbandingan kapabilitas proses yang dilakukan pihak perusahaan dengan metoda coba-coba, dan komposisi optimal yaitu untuk tingkat konsistensi sebesar 0.47 meningkat menjadi 1.11, tingkat freeness sebesar 0.45 meningkat menjadi 1.14 dan internal bonding sebesar 0.55 meningkat menjadi 1.15 .

\section{Daftar pustaka:}

Connie M.Borror, Editor,.2008.The Certified Quality Engineer Handbook.American Society for Quality.Quality Press,Milwaukee.United States of America.

DouglasC.Montgomery,.2009.Statistical Quality Control,John Wiley \& Sons Inc, Arizona

Douglas C.Montgomery,.2009.Design and Analysis of Experiments, John Wiley \& Sons Inc, Arizona.

Walhi,.2009.Perjalalanan Secarik Kertas.suatu tinjauan terhadap industry pulp dan kertas di Indonesia,Jakarta.

Direktorat Jendral Industri Agro dan Kimia, 2009. Roadmap Industri Kertas, Jakarta. 